FEATURE

Katherine Kent

Office for National Statistics

\section{SUMMARY}

This article describes the employment patterns of households and families using the Annual Population Survey (APS) household datasets. The household datasets are designed for analysis at the family and household level, and for person level analyses involving the characteristics of the family or households in which people live. The first part of this article concentrates on the economic activity status and composition of households in the United Kingdom. The second part of the article describes employment patterns within families and highlights the employment rates among couple mothers and lone mothers.

\title{
Households, families and work
}

\section{Introduction}

$\Lambda$ nalysing family and household characteristics compliments the wealth of available information on the characteristics of employed, unemployed and economically inactive people in the UK. For example employment rates of men and women are regularly published but there is also interest in how an individual's parental status influences their decision to work. The Government has a commitment to reduce child poverty and maximise employment opportunities for all. To monitor these targets, the employment rates of parents, the number of workless households (where no adults are working) and the number of children living within them are useful indicators.

\section{Annual Population Survey}

New annual local area datasets called the Annual Population Survey (APS) household datasets were launched by ONS in Autumn 2008. They allow production of family and household labour market statistics at local areas and for small sub-groups of the population across the UK.

The APS household dataset is derived from the Labour Force Survey (LFS) and the APS (person) dataset. It contains information collected from a sample of around 160,000 households. The APS household dataset aims to provide information on a minimum of 510 economically active people for each Local Area Authority and Unitary Authority. It is the recommended source for detailed family and household local area data because of the greater sample size. The LFS household data set is available for the three months to June of each year from 1997 and three months to December from 2004 for national level family analysis. The APS household datasets are available for January to December from 2004. This article mainly uses estimates for January to December 2007. When showing a longer time series the LFS is used, but only at national level.

\section{Household composition}

Table 1a shows the number of households in the UK with and without dependent children by the age of the adult household members. In the 12 months to December 2007 there were 25.5 million households in the UK. Of which 7.4 million (28.9 per cent) contained dependent children and 18.1 million (71.1 per cent) were without. Of those without dependent children, 6.1 million households contained only adults above state pension age.

Table $\mathbf{1 b}$ shows the number of households in the UK in the 12 months to December 2007 by household type. Of those households without dependent children, 7.4 million were one person households, 9.0 million were couple households, 0.9 million were lone parent households and a further 0.9 million were other types of households. This latter group includes households such as friends sharing. Of those households with dependent children the majority, 5.5 million were couple households. A further 1.8 million were lone parent households and the remaining 0.2 million were other household types.

Note that not all lone parents are 
Box 1

\section{Concepts and definitions}

Dependent children are children aged under 16 and those aged 16 to 18 who have never-married and are in full-time education.

Parents below state pension age are fathers aged 16 to 64 and mothers aged 16 to 59 who have one or more dependent children either living with them or away at boarding school or in university halls of residence. Adoptive and step-parents are included in this analysis, but foster parents and those who live in a separate household from their children are not.
The household reference person (HRP) is the person who owns the accommodation, or is legally responsible for the rent, or has the accommodation tied to a job or has the accommodation under a relationship to the owner who is not a member of the household.

\section{Table 1a}

\section{Number of households by age of adult members, January to December 2007}

United Kingdom

Thousands and percentages

\begin{tabular}{lrr}
\hline & $\begin{array}{r}\text { Households } \\
\text { (thousands) }\end{array}$ & $\begin{array}{r}\text { Percentage of all } \\
\text { households }\end{array}$ \\
\hline Total Households & 25,490 & 100.0 \\
& & 71.1 \\
$\begin{array}{l}\text { Households without dependent children }{ }^{1} \\
\text { of which: }\end{array}$ & 18,112 & 39.7 \\
$\begin{array}{l}\text { All adults below state pension age } \\
\text { Mixture of adults below and above state pension age }\end{array}$ & 10,107 & 7.3 \\
All adults above state pension age & 1,860 & 24.1 \\
& 6,145 & 28.9 \\
Households with dependent children & & \\
of which: & 7,377 & 28.2 \\
All adults below state pension age & 7,194 & 0.7 \\
Mixture of adults below and above state pension age & 176 & 0.0 \\
All adults above state pension age & 7 & \\
\hline
\end{tabular}

Note:

Source: Annual Population Survey Household dataset

1 Dependent children are those under 16 and those aged 16 to 18 who have never-married and are in full-time education.

\section{Table $1 \mathrm{~b}$}

Number of households by household type, January to December 2007

United Kingdom

Thousands and percentages

\begin{tabular}{|c|c|c|}
\hline & $\begin{array}{l}\text { Households } \\
\text { (thousands) }\end{array}$ & $\begin{array}{r}\text { Percentage of all } \\
\text { households } \\
\end{array}$ \\
\hline All households & 25,490 & 100.0 \\
\hline $\begin{array}{l}\text { Households without dependent children }{ }^{1} \\
\text { of which: }\end{array}$ & 18,112 & 71.1 \\
\hline One person households & 7,408 & 29.1 \\
\hline Couple households & 8,980 & 35.2 \\
\hline Lone parent households & 861 & 3.4 \\
\hline Other types of households & 863 & 3.4 \\
\hline $\begin{array}{l}\text { Households with dependent children }{ }^{1} \\
\text { of which: }\end{array}$ & 7,377 & 28.9 \\
\hline Couple households & 5,465 & 21.4 \\
\hline Lone parent households & 1,753 & 6.9 \\
\hline Other types of households & 159 & 0.6 \\
\hline
\end{tabular}

Note:

Source: Annual Population Survey Household dataset

1 Dependent children are those under 16 and those aged 16 to 18 who have never-married and are in full-time education.

captured as a lone parent household. For example a lone parent living with his or her parents and siblings may be classed as a couple household with others.

When reporting on key household labour market statistics such as the number of households where no adults are working, figures are restricted to households containing at least one adult below state pension age. That is women aged 16 to 59 and men aged 16 to 64 . This is because for around nine in ten households where all adults are above state pension age, no one is in work as most are retired from the labour market. Therefore analysis in this article is based on households containing at least one adult below state pension age. There are 19.3 million of these households of which, 11.9 million (61.8 per cent) are couple households, 3.8 million (19.8 per cent) are one person households, 2.6 million (13.4 per cent) are lone parent households and the remaining 1.0 million (5.0 per cent) are other types of household.

\section{Economic status of household}

A household can be defined as working, mixed or workless based on the economic activity status of the adults within the household. If all adults are in employment it is a working household, where none of the adults are employed, this is a workless household. Finally, if at least one adult is working and another is unemployed or inactive, then it is a mixed household. Note that a household where an adult below state pension age is working but lives with an elderly relative who isn't working, it is a mixed household.

Table 2 shows the number and percentage of households by household type based on the working status of individuals living within them. In the 12 months to December 2007 there were 11.1 million (57.2 per cent) working households, 5.3 million ( 27.2 per cent) mixed households and 3.0 million (15.6 per cent) workless households.

\section{Characteristics of households}

The following section describes the characteristics of working, mixed and workless households by household type, housing tenure and age of household reference person.

Household type

Of the 11.1 million working households, around two thirds are households without dependent children and the remaining are those with dependent children. Considering 
Table 2

Number and percentage of households ${ }^{1}$ by type and working status of household, January to December 2007

United Kingdom

\begin{tabular}{|c|c|c|c|c|}
\hline & $\begin{array}{r}\text { Working } \\
\text { households }\end{array}$ & $\begin{array}{r}\text { Mixed } \\
\text { households }\end{array}$ & $\begin{array}{r}\text { Workless } \\
\text { households }\end{array}$ & $\begin{array}{r}\text { Total } \\
\text { households } \\
\end{array}$ \\
\hline All households (thousands) & 11,061 & 5,260 & 3,016 & 19,337 \\
\hline Households without dependent children ${ }^{2}$ & 7,208 & 2,719 & 2,041 & 11,967 \\
\hline One person households & 2,739 & $\mathrm{n} / \mathrm{a}$ & 1,086 & 3,826 \\
\hline Couple households & 3,801 & 2,019 & 664 & 6,484 \\
\hline Lone parent households & 280 & 408 & 163 & 850 \\
\hline Other types of households & 388 & 292 & 128 & 807 \\
\hline Households with dependent children ${ }^{2}$ & 3,853 & 2,542 & 975 & 7,370 \\
\hline Couple households & 3,081 & 2,119 & 262 & 5,462 \\
\hline Lone parent households & 739 & 311 & 699 & 1,749 \\
\hline Other types of households & 34 & 111 & 14 & 159 \\
\hline All households (percentages) & 57.2 & 27.2 & 15.6 & 100.0 \\
\hline Households without dependent children ${ }^{2}$ & 60.2 & 22.7 & 17.1 & 100.0 \\
\hline One person households & 71.6 & $\mathrm{n} / \mathrm{a}$ & 28.4 & 100.0 \\
\hline Couple households & 58.6 & 31.1 & 10.2 & 100.0 \\
\hline Lone parent households & 32.9 & 47.9 & 19.1 & 100.0 \\
\hline Other types of households & 48.0 & 36.1 & 15.9 & 100.0 \\
\hline Households with dependent children ${ }^{2}$ & 52.3 & 34.5 & 13.2 & 100.0 \\
\hline Couple households & 56.4 & 38.8 & 4.8 & 100.0 \\
\hline Lone parent households & 42.3 & 17.8 & 39.9 & 100.0 \\
\hline Other types of households & 21.2 & 70.1 & 8.7 & 100.0 \\
\hline
\end{tabular}

Notes:

Source: Annual Population Survey Household dataset

1 Containing at least one woman aged 16 to 59 or a man aged 16 to 64 .

2 Dependent children are those under 16 and those aged 16 to 18 who have never-married and are in full-time education. those households without dependent children, of the 3.8 million one person households, 71.6 per cent were working households and the remaining 28.4 per cent workless. For the other household types, lone parents with dependent children had the highest workless rate of 39.9 per cent, more than double the rate of lone parents without dependent children. For couple households with dependent children, the workless rate was lowest. At 4.8 per cent it was around a half of the rate for couple households without dependent children, suggesting that as a couple, at least one adult is more likely to work if having a dependent child.

\section{Housing tenure}

Table 3 shows the percentage of households by working status and housing tenure. Of those that are owner occupied, 61.4 per cent were working households, 24.8 per cent were mixed households and the remaining 13.8 per cent were workless households. Rented or rent-free households have much lower working rates and higher workless rates. The working rate for this group of households was 43.0 per cent, the mixed rate was 23.1 per cent and the workless rate was 33.9 per cent.
However there are differences in the rates of households that are working and workless for sub-groups of housing tenure. For those that are owner occupied, households where the home is owned outright have a much lower working rate than those who are buying the home with a mortgage. The working rate was 42.5 per cent for households that are owned as opposed to a rate of 71.8 per cent for mortgaged homes. Thus the workless rate for households being bought with a mortgage was lower than those owned outright. At 3.1 per cent this shows the need to work when a mortgage has to be paid as opposed to households which are owned outright where 18.3 per cent were workless. Of the rented and rent-free group, socially rented households were much more likely to be workless than privately rented households, 46.0 per cent of socially rented households were workless compared with 20.2 per cent of those privately rented.

Age of household reference person Table 4 shows the percentage of households by working status and age group of the household reference person (HRP), see concepts and definitions. The working rate was highest for households where the HRP was aged between 25 and 34 at 71.5 per cent. The lowest working rate was in households were the HRP was aged between 50 and state pension age. The highest workless rate was where the HRP was aged between 16 and 24 at 29.2 per cent. While the lowest workless rate was in households were the HRP was aged between 35 and 49 at 10.8 per cent.

\section{Families}

There are more families than households since a household can contain more than one family. In the 12 months to December 2007, there were 21.1 million families where at least one adult in the family is below state pension age. Concentrating on families fully measures particular family types such as lone parents.

Working and workless families can be defined in a similar way to working and workless households. Workless families
Table 3

\section{Percentage of households ${ }^{1}$ by housing tenure and working status of household, January to December 2007}

United Kingdom

rcentages

\begin{tabular}{|c|c|c|c|c|}
\hline & $\begin{array}{r}\text { Working } \\
\text { households }\end{array}$ & $\begin{array}{r}\text { Mixed } \\
\text { households }\end{array}$ & $\begin{array}{r}\text { Workless } \\
\text { households }\end{array}$ & $\begin{array}{r}\text { Total } \\
\text { households } \\
\end{array}$ \\
\hline Owner occupied & 61.4 & 24.8 & 13.8 & 100.0 \\
\hline Owned & 42.5 & 39.1 & 18.3 & 100.0 \\
\hline Buying with a mortgage ${ }^{2}$ & 71.8 & 25.0 & 3.1 & 100.0 \\
\hline Rented/rent free & 43.0 & 23.1 & 33.9 & 100.0 \\
\hline Social rented ${ }^{3}$ & 29.9 & 24.1 & 46.0 & 100.0 \\
\hline Privately rented & 57.7 & 22.1 & 20.2 & 100.0 \\
\hline Total $^{4}$ & 57.2 & 27.2 & 15.6 & 100.0 \\
\hline
\end{tabular}

Notes:

Source: Annual Population Survey Household dataset

1 Containing at least one woman aged 16 to 59 or a man aged 16 to 64 .

2 Includes part-rent part-mortgage.

3 Local authority or housing association.

4 Includes a small number of households with other types of housing tenure. 
Table 4

\section{Percentage of households ${ }^{1}$ by age of household reference person and working status of household, January to December 2007}

\begin{tabular}{lrrrr} 
United Kingdom & $\begin{array}{r}\text { Working } \\
\text { households }\end{array}$ & $\begin{array}{r}\text { Mixed } \\
\text { households }\end{array}$ & $\begin{array}{r}\text { Workless } \\
\text { households }\end{array}$ & $\begin{array}{r}\text { Total } \\
\text { households }\end{array}$ \\
\hline $16-24$ & 51.4 & 19.3 & 29.2 & 100.0 \\
$25-34$ & 71.5 & 15.5 & 13.1 & 100.0 \\
$35-49$ & 62.8 & 26.4 & 10.8 & 100.0 \\
$50-$ state retirement age & 49.2 & 32.1 & 18.7 & 100.0 \\
& & & 15.6 & 100.0
\end{tabular}

Notes:

Source: Annual Population Survey Household dataset

1 Containing at least one woman aged 16 to 59 or a man aged 16 to 64 .

2 Include households where HRP is aged above state pension age, but other adult members are below state pension age.

Table 5

Percentage of families ${ }^{1}$ by family type and working status of family, January to December 2007

United Kingdom

Thousands and percentages

\begin{tabular}{lccrr}
\hline & $\begin{array}{c}\text { Working } \\
\text { families }\end{array}$ & $\begin{array}{r}\text { Mixed } \\
\text { families }\end{array}$ & $\begin{array}{r}\text { Workless } \\
\text { families }\end{array}$ & $\begin{array}{r}\text { Total } \\
\text { families }\end{array}$ \\
\hline All families (thousands) & 12,582 & 4,810 & 3,755 & 21,147 \\
All families (percentages) & 59.5 & 22.7 & 17.8 & 100.0 \\
& & & & \\
One person families & 69.8 & $n / a$ & 4.9 & 100.0 \\
Couple families with dependent children & 56.9 & 38.3 & 100.0 \\
Couple families without dependent children & 59.9 & 29.7 & 10.4 & 100.0 \\
Lone parent families with dependent children & 43.6 & 15.6 & 40.8 & 100.0 \\
Lone parent families with non-dependent children & 33.9 & 46.6 & 19.5 & 100.0 \\
\hline
\end{tabular}

Notes:

Source: Annual Population Survey Household dataset

1 Containing at least one woman aged 16 to 59 or a man aged 16 to 64 .

with dependent children are those with no resident parent in employment. Some families may contain children over 16 years old, who may be in employment, but in this analysis the status of the family is based on the employment status of the parents only.

Table 5 shows the number and percentage of families by working status and family type.

Of the 21.1 million families, 59.5 per cent were working, 22.7 per cent were mixed and 17.8 per cent were workless families. There is a smaller proportion of mixed families than households as families are more likely to contain only one adult, so there are more working and workless families.

By family type, one person families have the highest working rate at 69.8 per cent while lone parent families with dependent children have the highest workless rates at 40.8 per cent. For couple families with dependent children only 4.9 per cent are workless.

\section{Employment of people by parental status}

Analysing employment status of individual people within families, additionally to looking at family units, allows comparison of men and women within families with and without dependent children. This section compares the three main groups of which two have dependent children, married or cohabiting couples and lone parents and a third group consists of people without dependent children. Married and cohabiting couples consist of married couples, cohabiting couples, same sex cohabiting couples and civil partners aged 16 to state pension age.

Table 6 shows the employment rates of adults below state pension age by parental status and the Government Office regions of England, plus Wales, Scotland and Northern Ireland. For the UK as a whole the employment rate among married or cohabiting parents was 81.4 per cent. This is 8.5 percentage points higher than the employment rate of people without dependent children, which was 72.9 per cent and 16.7 percentage points higher than the lone parent employment rate at 56.2 per cent. Within regions, the employment rate for married or cohabiting parents was lowest in Inner London, at 66.4 per cent, and highest in the South West at 85.2 per cent. The highest lone parent employment rate was 64.8 per cent in the South East and lowest in Inner London at 41.5 per cent. The employment rate of people without dependent children was highest in the South East at 77.6 per cent and lowest in Northern Ireland at 65.9 per cent.

Married or cohabiting fathers had higher employment rates than married or cohabiting mothers (91.4 per cent compared with 71.4 per cent), whereas men and women without dependent children have similar employment rates. This indicates that having dependent children influences a parent's decision to work. With more men going to work while women look after the family and home. Lone mothers had the lowest employment rates of all these subgroups at 55.4 per cent. The biggest differential in employment rates of married or cohabiting mothers and fathers was in Inner London. The employment rate of married or cohabiting fathers was 31.9 percentage points higher than the employment rate of married or cohabiting mothers 82.5 per cent compared with 50.6 per cent.

\section{Mothers}

According to the Department of Work and Pensions (DWP) report on persistent poverty (Barnes, Conolly \& Tomaszewski, 2008) lone parents were four times more likely to be in persistent poverty than couple families (27.0 per cent compared to 6.0 per cent). Almost half (46 per cent) of lone parents who were not in work were in persistent poverty. Other characteristics identified as being associated with an increased risk of poverty include having three or more children, having a child aged up to four years old, being a young mother (under 25 years old) and being a black minority ethnic (BME) mother.

Employment rates of married or cohabiting mothers and lone mothers by various personal and family characteristics can be compared using the APS.

Table 7 shows the employment rates of married or cohabiting mothers and lone mothers with dependent children by various personal characteristics. Overall lone mothers have an employment rate of 55.4 per cent which is 16.0 percentage points lower than couple mothers at 71.4 per cent.

\section{Age}

For all age groups, lone mothers have lower employment rates than couple mothers and the age of the mother has an impact on the employment rate for both groups. As the age of the mother increases, the employment rate also increases. For 
Table 6

Employment rates of people ${ }^{1}$ by parental status and Government Office region, January to December 2007

\begin{tabular}{|c|c|c|c|c|c|c|c|c|c|c|}
\hline & & & & & & & & & & tages \\
\hline & $\begin{array}{r}\text { Married/ } \\
\text { cohabiting } \\
\text { parents }^{2}\end{array}$ & $\begin{array}{c}\text { Married/ } \\
\text { cohabiting } \\
\text { mothers }^{2}\end{array}$ & $\begin{array}{r}\text { Married/ } \\
\text { cohabiting } \\
\text { fathers }^{2}\end{array}$ & $\begin{array}{r}\text { Lone } \\
\text { parents }^{2}\end{array}$ & $\begin{array}{r}\text { Lone } \\
\text { mothers }^{2}\end{array}$ & $\begin{array}{r}\text { Lone } \\
\text { fathers }^{2}\end{array}$ & $\begin{array}{r}\text { People } \\
\text { without } \\
\text { dependent } \\
\text { children }\end{array}$ & $\begin{array}{r}\text { Women } \\
\text { without } \\
\text { dependent } \\
\text { children }\end{array}$ & $\begin{array}{r}\text { Men without } \\
\text { dependent } \\
\text { children } \\
\end{array}$ & Total \\
\hline United Kingdom & 81.4 & 71.4 & 91.4 & 56.2 & 55.4 & 65.7 & 72.9 & 72.3 & 73.3 & 74.6 \\
\hline Great Britain & 81.4 & 71.4 & 91.4 & 56.4 & 55.5 & 66.4 & 73.1 & 72.6 & 73.5 & 74.7 \\
\hline England & 81.1 & 70.8 & 91.5 & 56.4 & 55.5 & 66.4 & 73.2 & 72.6 & 73.7 & 74.7 \\
\hline North East & 81.7 & 74.4 & 88.9 & 53.4 & 53.7 & 49.6 & 69.1 & 69.9 & 68.5 & 71.8 \\
\hline North West & 81.5 & 73.5 & 89.6 & 54.6 & 54.0 & 61.1 & 70.2 & 70.2 & 70.2 & 72.6 \\
\hline Yorkshire \& the Humber & 80.7 & 70.9 & 90.4 & 57.3 & 56.0 & 73.3 & 71.2 & 70.9 & 71.5 & 73.4 \\
\hline East Midlands & 83.7 & 74.0 & 93.5 & 60.4 & 58.5 & 76.4 & 73.5 & 73.0 & 73.9 & 76.0 \\
\hline West Midlands & 79.4 & 68.9 & 90.0 & 56.9 & 56.1 & 65.4 & 71.0 & 69.7 & 72.0 & 72.8 \\
\hline East & 82.1 & 71.1 & 93.1 & 60.9 & 59.7 & 74.5 & 77.0 & 75.6 & 78.2 & 77.9 \\
\hline London & 74.1 & 59.5 & 88.9 & 44.7 & 44.3 & 49.7 & 70.9 & 69.5 & 72.1 & 70.2 \\
\hline Inner London & 66.4 & 50.6 & 82.5 & 41.5 & 41.4 & 42.8 & 69.7 & 68.5 & 70.8 & 67.2 \\
\hline Outer London & 78.1 & 64.1 & 92.1 & 47.3 & 46.7 & 55.5 & 71.8 & 70.3 & 73.1 & 72.3 \\
\hline South East & 83.2 & 72.3 & 94.1 & 64.8 & 63.6 & 79.0 & 77.6 & 77.4 & 77.8 & 78.9 \\
\hline South West & 85.2 & 77.3 & 93.1 & 64.0 & 63.3 & 71.3 & 76.1 & 75.4 & 76.7 & 78.2 \\
\hline Wales & 81.4 & 73.7 & 89.2 & 55.0 & 54.7 & 58.0 & 68.3 & 68.7 & 68.0 & 71.3 \\
\hline Scotland & 84.5 & 76.9 & 92.1 & 57.8 & 56.6 & 71.5 & 74.4 & 74.7 & 74.2 & 76.3 \\
\hline Northern Ireland & 81.5 & 72.9 & 90.0 & 49.6 & 50.4 & 39.6 & 65.9 & 63.4 & 67.8 & 69.9 \\
\hline
\end{tabular}

Notes:

Source: Annual Population Survey Household dataset

1 Women aged 16 to 59 and men aged 16 to 64 .

2 With dependent children, dependent children are those under 16 and those aged 16 to 18 who have never-married and are in full-time education.

\section{Table 7}

\section{Employment rate of mothers ${ }^{1}$ with dependent children, ${ }^{2}$ January to December 2007}

\begin{tabular}{|c|c|c|}
\hline \multirow[t]{2}{*}{ United Kingdom } & & Percentages \\
\hline & Married/cohabiting mothers & Lone mothers \\
\hline \multicolumn{3}{|l|}{ Age of mother } \\
\hline $16-18$ & 24.8 & 17.4 \\
\hline $19-24$ & 42.4 & 30.0 \\
\hline $25-34$ & 64.8 & 46.4 \\
\hline $35-44$ & 74.9 & 62.9 \\
\hline $45+$ & 77.9 & 68.6 \\
\hline \multicolumn{3}{|c|}{ Number of dependent children in family } \\
\hline one & 76.8 & 62.2 \\
\hline two & 73.0 & 54.3 \\
\hline three & 58.3 & 37.2 \\
\hline four + & 40.2 & 23.2 \\
\hline \multicolumn{3}{|c|}{ Highest qualification of mother } \\
\hline Degree of equivalent & 81.4 & 83.4 \\
\hline Higher educ & 83.6 & 78.9 \\
\hline GCE A Level or equiv & 77.2 & 67.7 \\
\hline GCSE grades $\mathrm{A}-\mathrm{C}$ or equiv & 72.4 & 56.3 \\
\hline Other qualifications & 58.5 & 46.0 \\
\hline No qualification & 38.2 & 25.7 \\
\hline \multicolumn{3}{|l|}{ Age of youngest child } \\
\hline 0 to 4 & 62.0 & 36.9 \\
\hline 5 to 10 & 75.5 & 57.4 \\
\hline 11 to 15 & 80.4 & 69.1 \\
\hline 16 to 18 & 79.8 & 77.4 \\
\hline Total & 71.4 & 55.4 \\
\hline
\end{tabular}

\section{Notes:}

Source: Annual Population Survey Household dataset

1 Aged 16 to 59 .

2 Dependent children are those under 16 and those aged 16 to 18 who have never-married and are in full-time education. married or cohabiting mothers aged 16 to 18 the employment rate was 24.8 per cent, rising to 77.9 per cent for mothers aged over 45 . For lone mothers aged 16 to 18 the employment rate was 17.4 per cent, rising to 68.6 per cent for those aged 45 and over. As the age of the mother increases it is more likely the age of the dependent children will increase and therefore it could be easier for older mothers to be in employment.

Number of dependent children in family

The number of dependent children in the family impacts on the likelihood of mothers being in employment for both those married or cohabiting and those on their own. As the number of dependent children increases, the employment rate decreases. Again married or cohabiting mothers have higher employment rates than lone mothers for each of the groups. Where there is one dependent child for the mother, the employment rate when married or cohabiting is 76.8 per cent and this falls by 36.6 percentage points to just 40.2 per cent where there are four or more dependent children. For lone mothers the gap in the employment rate is wider. For those with one dependent child the employment rate is 62.2 per cent, falling by 39.0 percentage points to just 23.2 per cent for those with four or more dependent children.

Highest qualification

The skill level of those in employment can be measured through the highest 
level of qualification held. Employment rates generally increase as the level of qualifications held by married or cohabiting mothers and lone mothers increase.

Married or cohabiting mothers with no qualifications had an employment rate of 38.2 per cent, rising to 83.6 per cent for those with a higher qualification. It was slightly lower at 81.4 per cent for those with a degree or equivalent qualification. Lone mothers with no qualifications had an employment rate of 25.7 per cent, rising to 83.4 per cent for those with a degree or equivalent qualification. Within the qualifications, degree or equivalent is the only characteristic in table 7 where the lone mother employment rate is higher than those married or cohabiting.

\section{Age of youngest child}

Age of youngest child is linked to the number of dependent children because the more children a mother has, the more likely one is to be within the youngest age group. Mothers with a dependent child aged up to four have the lowest employment rates, but there is a 25.1 percentage point difference between the employment rate of married or cohabiting mothers and lone mothers, 62.0 per cent and 36.9 per cent respectively. As the age of the youngest child increases the employment rate increased. For mothers who are married or cohabiting, the employment rate reaches a peak of 80.4 per cent where the age of the dependent child is 11 to 15 . For lone mothers the peak comes where the youngest child is 16 to 18 at 77.4 per cent.

\section{Employment rates of people by parental status over time}

For the last decade until the three months to June 2008, the employment rates for individuals and parental groups have been increasing. Figure 1 shows employment rates by parental status for the three months to June 1998 until the three months to June 2008 using the LFS.

The largest increase for each of the parental groups was in the employment rate for lone parents. In the three months to June 2008 it stood at 56.3 per cent up by 10.3 percentage points, from 46.0 per cent in the same period a decade earlier. The employment rate of lone parents is used as an indicator to monitor the Government target for full employment opportunity for all.

Figure 1

Employment rates of people ${ }^{1}$ by parental status 1998 to $2008^{2}$

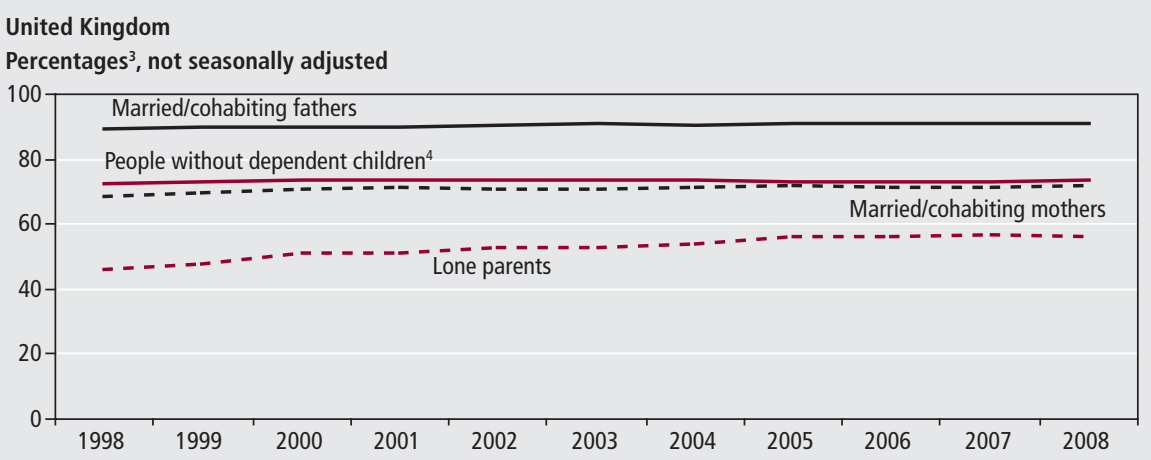

Notes:

Source: Labour Force Survey Household dataset

1 Men aged 16 to 64 and women aged 16 to 59.

2 April to June quarter.

3 Base for percentages excludes people with unknown employment status.

4 Dependent children are those under 16 and those aged 16 to 18 who have never-married and are in full-time education.

The smallest increase in the employment rate was for people without dependent children. The rate increased by just 1.0 percentage points over the decade to 73.5 per cent in the three months to June 2008.

\section{Conclusion}

This article has shown that of the many households in the UK over half (57.2 per cent) contain adults were everyone is in work and for around 1 in every 6 (15.6 per cent) households, there are no adults in work. However these proportions differ for the many sub-groups of household type. For example there is a high proportion of lone parent households with dependent children that are workless (39.9 per cent) compared with couple households with dependent children (4.8 per cent).

The tenancy status of households has an impact on the economic status of households. Where a house is being bought with a mortgage there are much higher rates of working households (71.8 per cent) compared with those that are socially rented (29.9 per cent). Consequently, the latter group have high workless rates $(46.0$ per cent) with a low workless rate (3.1 per cent) for households being bought with a mortgage.

Employment rates of individuals differ according to their personal circumstances. Married or cohabiting parents with dependent children have a much higher employment rate (81.4 per cent) compared with lone parents with dependent children (56.2 per cent). Of those married and cohabiting with dependent children, it is the fathers who have higher employment rates as opposed to the mothers, 91.4 per cent and 71.4 per cent respectively.

Of all mothers with dependent children, married and cohabiting mothers have higher employment rates than lone mothers. Of the many characteristics described in this article, the largest differential is for mothers whose children are aged under five. The employment rate of lone mothers was 36.9 per cent compared with a rate of 62.0 per cent for mothers who are married or cohabiting.

\section{CONTACT}

(凶)elmr@ons.gsi.gov.uk

\section{REFERENCES}

PSA delivery agreements and indicators can be found at:

www.hm-treasury.gov.uk/pbr_csr07_ psaindex.htm

M. Barnes, A. Conolly and W. Tomaszewski (2008) 'The circumstances of persistently poor families with children: Evidence from the Families and Children Study (FACS)'

Department for Work and Pensions Research Report No 487

A.Walling (2005) 'Families and Work' Labour Market Trends 112(7) pp275-84 